\title{
Techno-economic performance of 4-row self-propelled mechanical rice transplanter at farmers field in Bangladesh
}

\author{
AKMS Islam, MA Rahman, AKML Rahman, MT Islam, MI Rahman
}

Bangladesh Rice Research Institute, Gazipur, Dhaka, Bangladesh

\begin{abstract}
Mechanical transplanting is an emerging technology in Bangladesh agriculture. Deadong DP480 rice transplanter was used to conduct the experiment which is imported from South Korea and China. The performance of this machine needs to be thoroughly investigated in local condition. This experiment was conducted in Boro (2015) season in the farmers' field at Gosaidanga in Shailkupa upazila under Jhenaidah district and at Rashidpur in Mithapukur upazila under Rangpur district. Two treatments, i.e. T1 = Hand transplanting (HT) and T2= Mechanical transplanting (MT) were used in the experiment. The experiment was carried out in randomized complete block design (RCBD) and replicated in six plots in each location. Rice variety BRRI dhan 28 was used to conduct the experiment in both locations. Fuel consumption of 4-row walking type mechanical transplanter obtained $5.25 \mathrm{~L} / \mathrm{ha}$. The field capacity and field efficiency of rice transplanter obtained 0.11-0.12 ha/hr and 64-70 percent, respectively. Conventional seedbed preparation required 37-55 man-hr/ha whereas 71-77 man-hr/ha required in mat type seedling suitable for mechanical transplanting. Labor requirement in hand and mechanical transplanting ranged from 123-150 and 9.0-10.5 man-hr per hectare which was 19-22 and 1.65-2.00 percent of total labor requirement in rice cultivation, respectively. Number of seedling tray requirement ranged from 215-230 per hectare. Calibration should be done on space and seedling density setting before operation in each plot to get optimum plant spacing and seedling tray requirement. Missing hill obtained 1-2 percent in mechanically transplanted plot. Mechanically transplanted plot showed significantly the higher grain yield (9-14\%) than hand transplanted method due to use of infant seedling. The input cost in the form of labor and material was found similar in hand transplanting whereas in mechanical transplanting, labor cost found 12 percent lower than material cost. The cost of growing mat type seedling for mechanical transplanter found 53 percent whereas the cost of raising traditional seedbed found 34 percent of the cost of hand transplanting. Mechanical transplanting reduced 1.8 percent input cost than hand transplanting in crop cultivation. BCR of MT and HT showed 1.18-1.19 and 1.03-1.06, respectively. Mechanical intervention in crop production drastically reduced the labor requirement which can offset the peak labor demand. Mechanical transplanting systems increased yield, improved labor efficiency, ensured timeliness in operation and faster transplanting.
\end{abstract}

Key words: Fuel consumption, missing hill, labor requirement, yield, economics

Progressive Agriculturists. All rights reserve

\section{Introduction}

In Bangladesh, manual transplanting of rice seedlings into heavy puddled soils is the most important
*Corresponding Author: akmsaifulislam68@gmail.com

agricultural operations in crop production. Manual paddy transplanting is the tedious, laborious and time 
consuming operations requiring about 250-300 man $\mathrm{h}$ $\mathrm{ha}^{-1}$ which is roughly $25 \%$ of total labor requirement of rice production (Singh et al., 1985). The availability of labor becomes scarce and increases the wages, hand transplanting found costly leading to reduce profits in rice production. It was reported that a delay in transplanting by one month reduces the yield by $25 \%$ and a delay of two month reduced the yield by $70 \%$ (Rao and Pradhan, 1973). There is a very limited time between harvesting of one crop to sowing/transplanting of the next one. Due to shortage of human labor, farmers are compelled to practice delayed planting which results in yield loss. Farm labor is decreasing due to shifting on-farm to off-farm activity. Farm owners have been facing an acute crisis of labor in the peak time of transplanting due to shortage of labors and excessive cost in this season. Crisis of labor has created an unusual situation. The farm owners have to find the labors going door to door or they have to wait for the labors to finish the work in the nearby fields. Sometimes, they have to hire labor offering extra wages with additional facilities. As a result, the scheduled time of transplanting paddy expires in many places. Under such circumstances a less expensive and labor saving method of rice transplanting without yield loss is the urgent need of the hour (Tripathi et.al., 2004). It is therefore essential to adopt the mechanical transplanter to ensure the timeliness in planting. Mechanization will bring a fundamental change in agricultural labor and cultivation process in Bangladesh. Mechanical rice transplanting method generates employment and alternate sources of income for rural youth through custom services on nursery raising and transplanting. The mechanical transplanting of rice has been considered the most promising option, as it saves labor, ensures timely transplanting and attains optimum plant density that contributes to high productivity. However, rice transplanters are considerably expensive for almost all Asian small-hold farmers. It is popular in industrialized countries where labor cost is high, for example in South Korea. Seedling age is an important factor because it has a tremendous influence on the plant height, tiller production, panicle length, grain formation, grain panicle $^{-1}$ and other yield contributing characters. Mechanical transplanters use infant seedlings and do not require extra land to raise seedlings. The farmer of Bangladesh does not give attention to the age of seedlings at transplanting and use 30 or more day's age of seedling. For optimum yield, age of seedlings at transplanting of a particular variety at a particular season may not be suitable for other varieties at that season. Therefore, it is very important to find out the optimum age of seedling of a particular variety for a particular season. The growth, development, yield and yield components of rice all are greatly influenced by plant spacing. Optimum plant spacing ensures the plants to grow properly with their aerial and underground parts utilizing more solar radiation and nutrients. There is a significant trend to mechanization of rice production resulting in reducing the labor work and time consuming. Rice planting is one of the important stages in this viewpoint particularly in transplanting method. According to above and necessity of time saving and crop yield, in recent years, farmers were encouraged to adopt mechanized methods of rice transplanting. Mechanical transplanter has high field capacity and farmers can transplant rice seedlings within very short time by using mechanical transplanter. Recently, mechanical transplanter is introduced in our country. As a new technology, this machine needs to be evaluated in different agroecological zone and in different rice season. Therefore, the present study was undertaken to compare the cost of mechanical over traditional method of transplanting.

\section{Materials and Methods}

This experiment was conducted in the farmers' field at Gosaidanga in Shailkupa upazila under Jhenaidah district and at Rashidpur in Mithapukur upazila under Rangpur district. The experiment was carried out in randomized complete block design (RCBD) and replicated in six plots. Twelve plots within one kilometer radius were selected to conduct this study. 
Two treatments were used to conduct the experiments, which is $\mathrm{T} 1=$ Hand transplanting $(\mathrm{HT})$ and $\mathrm{T} 2=$ Mechanical transplanting (MT). Rice variety BRRI dhan28 were used to conduct the experiment in both locations. Self-propelled four rows walking-type rice transplanter (DP-480) was used to transplant seedling. It has a fixed row spacing of $30 \mathrm{~cm}$ and has provisions for adjustments of planting depth, number of seedlings per hill, floats pressure against soil, hill spacing and planting speed. The field was prepared using common tillage practice, which was first plowing (primary tillage) once, followed by puddling (secondary tillage) twice and leveling using two-wheel tractor under the flooding conditions. After first rotary tilling, the field was flooded with water and kept as such for 7 days and then second rotary tilling was done on 8th day and the field was leveled by a plank. The plastic trays were used to raise mat-type seedlings. Dry soil was filled in tray in such a way that the soil was free from any stone, stubble and grass. Sprouted seeds were spread uniformly over the tray. The seed rate per tray for mechanical transplanting was 130-140 gm dry seed. Traditional seedbed preparation often involved secondary tillage using spade and puddling was done after inundating the field. The seed rate for hand transplanting was $37.5 \mathrm{~kg} / \mathrm{ha}$. The nursery bed was made wet by application of water one day before uprooting the seedlings. The seedlings were uprooted on 9th January 2015 without causing much mechanical injury to the roots and immediately transferred to the main field.

During final land preparation, all cares were taken for uniform leveling of the land. Irrigation water was applied time to time as when required uniformly in hand and mechanical transplanted plots for proper growth and development of crops. Maximum irrigation was needed at the panicle initiation stage. In hand transplanting plot, forty two days (for Rangpur site) and forty six days (for Jhenaidah site) old seedlings were uprooted carefully from the nursery field and transplanted in each of the well puddled unit plots on two different days. The date of hand transplanting for
Boro rice was $10^{\text {th }}$ January in Rangpur site and $30^{\text {th }}$ January in Jhenaidah site (after harvesting mustard). In mechanical transplanting thirty three days (for Rangpur site) and twenty eight days (for Jhenaidah site) old seedlings were used for mechanical transplanting. Before starting the transplanter, seedling mat was rolled and fed to the mechanical transplanter and all the required adjustments such as hill spacing, number of plant per hill and planting depth were done based on the machine operator's manual. The date of transplanting for Boro rice was $9^{\text {th }}$ January in Rangpur site and $30^{\text {th }}$ January in Jhenaidah site. In mechanical transplanter, line to line distance was fixed at $30 \mathrm{~cm}$ and plant to plant spacing can be varied and set at 17 $\mathrm{cm}$. The amount of human labor involved in each operation was investigated through field measurements. Field efficiency and costs are calculated following the method mentioned in Hunt (1995).

\section{Comparative inputs}

Comparative inputs in two practices are given in Table $1 \mathrm{a}$ and $1 \mathrm{~b}$. Inputs were almost similar in both practices. Seedling age was higher in MT than HT. Seedling were raised in tray for mechanical transplanter whereas, farmers raised seedling in traditional seedbed. Rice variety, fertilizer rate, cultural practices, disease infestation depended on rice season. Micronutrient was applied in both practices.

\section{Cultural practices}

Weed infestation was not severe due to application of weedicide. Few weeds were grown in the plot. For the removal of weeds, weeding was done manually by hand once at 55 days after transplanting (DAT). After that no other weeding operation was done up to harvest. Pest infestation was severe and controlled by a single application of Virtako and Nativo at the vegetative growth stage.

\section{Yield and yield contributing character}

Grain yield were recorded from pre-selected $10 \mathrm{~m}^{2}$ land area and adjusted moisture content of 14\% moisture level. For computing aboveground biomass and yield 
contributing characters, 4 hills were collected from the outside of the selected area. The dry weight of straw was determined after oven-drying at $70^{\circ} \mathrm{C}$ to constant weight. Panicle number of each hill was counted to determine the panicle number $\mathrm{m}^{-2}$. Plant samples were separated into straw and panicles. Panicles were handthreshed and the filled spikelets were separated from unfilled spikelets. Aboveground total biomass was the total dry matter of straw, rachis, and filled and unfilled spikelets. Spikelets per panicle, grain-filling percentage $(100 \times$ filled spikelet number/total spikelet number), and harvest index $(100 \times$ filled spikelet weight/aboveground total biomass) were calculated. Border areas of all sides of the plot were excluded to avoid border competition effects.

\section{Economic analysis}

In order to estimate the production cost, the data on working speed, total time and labor involvement and materials inputs to complete the operation were recorded.

Table 1a. Comparative input in two practices at Rangpur site

\begin{tabular}{|c|c|c|c|}
\hline Sl. no. & Parameters & MT & HT \\
\hline 1 & Variety & BRRI dhan28 & BRRI dhan28 \\
\hline 2 & Date of Seeding & $06 / 12 / 14$ & $28 / 11 / 14$ \\
\hline 3 & Seed rate & $130-140$ gm dry seed/tray & $37.5 \mathrm{~kg} / \mathrm{ha}$ \\
\hline 4 & Seedling raising technique & Plastic tray method & Traditional seedbed \\
\hline 5 & Transplanting & Mechanical & Hand \\
\hline 6 & Date of transplanting & $09 / 01 / 15$ & $10 / 01 / 15$ \\
\hline 7 & Age of seedling & 33 days & 42 days \\
\hline 8 & Spacing & $30 \times 17 \mathrm{~cm}$ & Almost line sowing \\
\hline 9 & Tray requirement & 230 tray/ha & - \\
\hline 10 & Seedling density setting & Medium & - \\
\hline \multirow[t]{3}{*}{$11 \mathrm{a}$} & Basal Fertilizer & TSP@136kgha ${ }^{-1}$ & TSP@136kgha ${ }^{-1}$ \\
\hline & & MOP@111 $\mathrm{kgha}^{-1}$ & MOP@111 $\mathrm{kgha}^{-1}$ \\
\hline & & 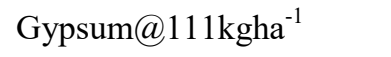 & Gypsum@111 kgha ${ }^{-1}$ \\
\hline $11 \mathrm{~b}$ & Micro Nutrient & $\underline{\mathrm{Zn} @ 11.25 \mathrm{kgha}^{-1}}$ & $\underline{\mathrm{Zn} @, 11.25 \mathrm{kgha}^{-1}}$ \\
\hline 12 & Weedicide & Superclean@0.75kg ha ${ }^{-1}$ & Superclean@0.75kg ha ${ }^{-1}$ \\
\hline 13 & Time of application & $12 / 01 / 2015$ & $13 / 01 / 2015$ \\
\hline 14 & Weeding & one time & 2 times \\
\hline 15 & Top dressing & Urea $272 \mathrm{kgha}^{-1}$ & Urea $272 \mathrm{kgha}^{-1}$, DAP $50 \mathrm{kgha}^{-1}$ \\
\hline $15 \mathrm{a}$ & 1st top dress & Urea $99 \mathrm{kgha}^{-1}$ & Urea $99 \mathrm{kgha}^{-1}$ \\
\hline $15 b$ & 2nd top dress & Urea $124 \mathrm{kgha}^{-1}$ & Urea $124 \mathrm{kgha}^{-1}$ \\
\hline $15 \mathrm{c}$ & 3rd top dress & Urea $49 \mathrm{kgha}^{-1}$ & Urea $49 \mathrm{kgha}^{-1}$ \\
\hline \multirow[t]{2}{*}{16} & Insecticide & Virtako one time & Virtako one time \\
\hline & & (@) $75 \mathrm{~g} \mathrm{ha}^{-1}$ & @ $75 \mathrm{~g} \mathrm{ha}^{-1}$ \\
\hline \multirow[t]{4}{*}{17} & Fungicide & Nativo one time & Nativo one time \\
\hline & & (a) $300 \mathrm{~g} \mathrm{ha}^{-1}$ & (a) $300 \mathrm{~g} \mathrm{ha}^{-1}$ \\
\hline & & Trooper one time & Trooper one time \\
\hline & & (a) $2.25 \mathrm{~kg} \mathrm{ha}^{-1}$ & (a) $2.25 \mathrm{~kg} \mathrm{ha}^{-1}$ \\
\hline 18 & Date of maturity & $24 / 04 / 15$ & $28 / 04 / 15$ \\
\hline
\end{tabular}


Table 1b. Comparative input in two practices at Jhenaidah site

\begin{tabular}{|c|c|c|c|}
\hline SI. no. & Parameters & MT & HT \\
\hline 1 & Variety & BRRI dhan28 & BRRI dhan28 \\
\hline 2 & Date of Seeding & $02 / 01 / 15$ & $15 / 12 / 14$ \\
\hline 3 & Seed rate & $130-140$ gm dry seed/tray & $37.5 \mathrm{~kg} / \mathrm{ha}$ \\
\hline 4 & Seedling raising technique & Plastic tray method & Traditional seedbed \\
\hline 5 & Transplanting & Mechanical & Hand \\
\hline 6 & Date of transplanting & $30 / 01 / 15$ & $30 / 01 / 15$ \\
\hline 7 & Age of seedling & 28 days & 46 days \\
\hline 8 & Spacing & $30 \times 17 \mathrm{~cm}$ & Almost line sowing \\
\hline 9 & Tray requirement & 215 tray/ha & - \\
\hline 10 & Seedling density setting & Medium & - \\
\hline \multirow[t]{3}{*}{$11 \mathrm{a}$} & Basal Fertilizer & TSP@90kgha ${ }^{-1}$ & TSP@90kgha ${ }^{-1}$ \\
\hline & & MOP@112kgha ${ }^{-1}$ & MOP@112kgha ${ }^{-1}$ \\
\hline & & Gypsum@90kgha ${ }^{-1}$ & Gypsum@90kgha ${ }^{-1}$ \\
\hline $11 \mathrm{~b}$ & Micro Nutrient & $\underline{\mathrm{Zn} @, 7.5 \mathrm{kgha}^{-1}}$ & $\underline{\mathrm{Zn} @ 7.5 \mathrm{~kg} \mathrm{ha}^{-1}}$ \\
\hline 12 & Weedicide & Pyrogold@124kgha ${ }^{-1}$ & Pyrogold@124kgha ${ }^{-1}$ \\
\hline 13 & Time of application & $04 / 02 / 2015$ & $04 / 02 / 2015$ \\
\hline 14 & Weeding & One time & 2 times \\
\hline 15 & Top dressing & Urea $198 \mathrm{kgha}^{-1}$ & Urea $198 \mathrm{kgha}^{-1}$ \\
\hline $15 \mathrm{a}$ & 1st top dress & Urea $74 \mathrm{kgha}^{-1}$ at 25 DAT & Urea $74 \mathrm{kgha}^{-1}$ at $25 \mathrm{DAT}$ \\
\hline $15 b$ & 2nd top dress & Urea $124 \mathrm{kgha}^{-1}$ at 55 DAT & Urea $124 \mathrm{kgha}^{-1}$ at $55 \mathrm{DAT}$ \\
\hline \multirow[t]{2}{*}{16} & Insecticide & Virtako one time & Virtako one time \\
\hline & & (@) $75 \mathrm{~g} \mathrm{ha}^{-1}$ & $@ 75 \mathrm{~g} \mathrm{ha}^{-1}$ \\
\hline \multirow[t]{4}{*}{17} & Fungicide & Nativo one time & Nativo one time \\
\hline & & @ $300 \mathrm{~g} \mathrm{ha}^{-1}$ & (a) $300 \mathrm{~g} \mathrm{ha}^{-1}$ \\
\hline & & Trooper one time & Trooper one time \\
\hline & & (a) $2.25 \mathrm{~kg} \mathrm{ha}^{-1}$ & (a) $2.25 \mathrm{~kg} \mathrm{ha}^{-1}$ \\
\hline 18 & Date of maturity & $13 / 05 / 15$ & $14 / 05 / 15$ \\
\hline
\end{tabular}

Rental charge of the machines was also included in the cost estimation. Land rental value and interest on investment were considered to calculate the total input cost. Price of the produce was collected from the local markets to compute total production cost, gross return, gross margin and benefit-cost ratio.

\section{Statistical analysis}

Statistical analysis was done by using software Statistix 9.0. Least significant difference was used to compare the means.

\section{Result and Discussion}

\section{Seedling age}

In mat type seedling, 25-30 days age found optimum for transplanting whereas farmers transplant 45 daysold seedling in cold season Seedling age obtained higher in cold season than warm season.

\section{Fuel consumption}

Fuel consumption varied from 4.50-6.00 1/ha (Rangpur site) and 5.00-5.50 1/ha (Jhenaidah site) L/ha. The fuel consumption varied in two locations due to soil type, 
water height, plot size and shape. Average fuel consumption obtained $5.25 \mathrm{~L} / \mathrm{ha}$.

\section{Field capacity of mechanical transplanting}

Field capacity is an important factor for any kind of machine operation. Mechanical transplanter transplanted $0.10-0.12 \mathrm{ha} / \mathrm{hr}$. The field efficiency of transplanter was 64-70 percent, respectively.

\section{Seedling tray requirement}

Seedling tray requirement depended on space setting. Seedling tray requirement in mechanical transplanting ranged from 215-230 number per hectare in both locations. Calibration should be done on seedling density setting to optimize seedling tray requirement.

\section{Plant to plant spacing}

In mechanical transplanter, line to line spacing was fixed at $30 \mathrm{~cm}$ whereas, plant to plant spacing can be varied. Plant to plant spacing was set $17 \mathrm{~cm}$. In practical situation, most of the places plant to plant spacing was not consistent and sometimes higher and lower than $17 \mathrm{~cm}$ (Figure 1). This might be due to skidding or slippage of the transplanter as a result of water height and depth of puddled soil. It was the common phenomenon which occurred frequently in the field. The average plant spacing of mechanical transplanter was obtained $18.06-18.41 \mathrm{~cm}$ which was higher than the set point. Behera et al. (2009) reported that the plant spacing not only depends on the puddling methods, but also influenced by sedimentation period (the period between the end of puddling and start of transplanting); higher sedimentation period more was plant spacing. Calibration should be done on space setting before operation in each plot to get optimum plant spacing.

\section{Missing hill}

In mechanical transplanting, missing hill was observed $1-2 \%$ in both sites. Missing hill was insignificant in mechanically transplanted plot. Missing hill was found lessthan the allowable limit of 5\% (Mori, 1975). Gap filling was done 3-4 days after transplanting. Missing hill was not found in the manual transplanting as the laborers carefully transplant the seedlings into puddled soil.

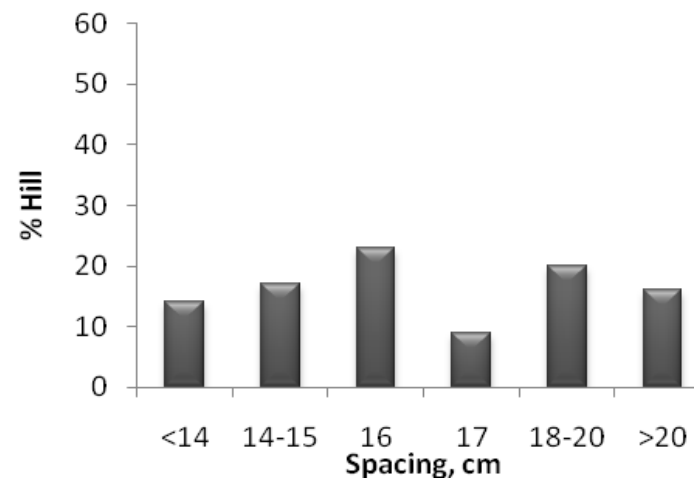

(a) Rangpur site

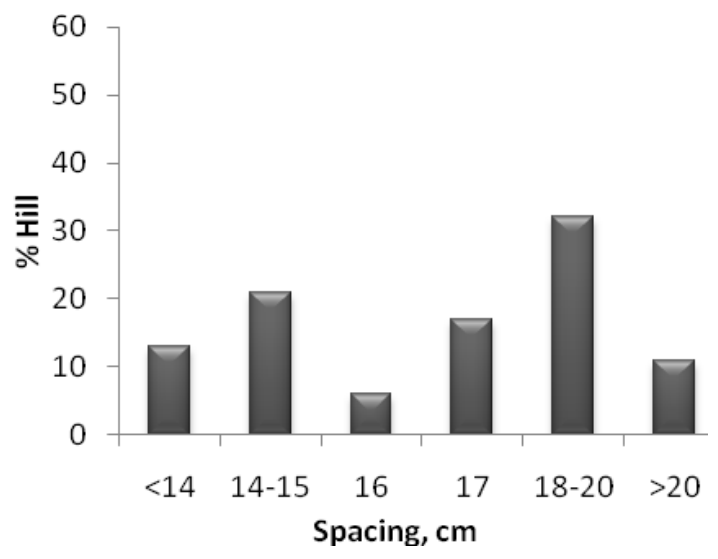

(b) Jhenaidah site

Figure 1. Distribution of seedling spacing under machine spacing setting

\section{Hill density}

Figure 2 showed the hill density of mechanical transplanting over manual transplanting. In mechanically transplanted plot, hill density was higher in Rangpur than Jhenaidah site. Hill density of MT was inconsistent in both locations. It might be due to slippage and skidding of the machine caused by water height, puddled depth and land leveling. In HT, hill density showed higher in Jhenaidah which might be due to laborers transplanted seedling by eye estimation and unable to maintain proper plant spacing. In both 
locations, plant to plant spacing observed highest and line to line spacing observed lowest in HT than MT.

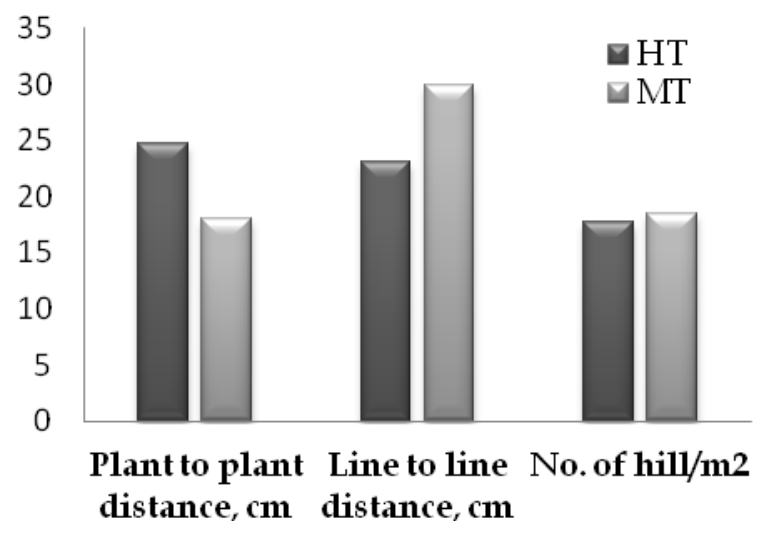

Figure 2a. Hill density at Rangpur site

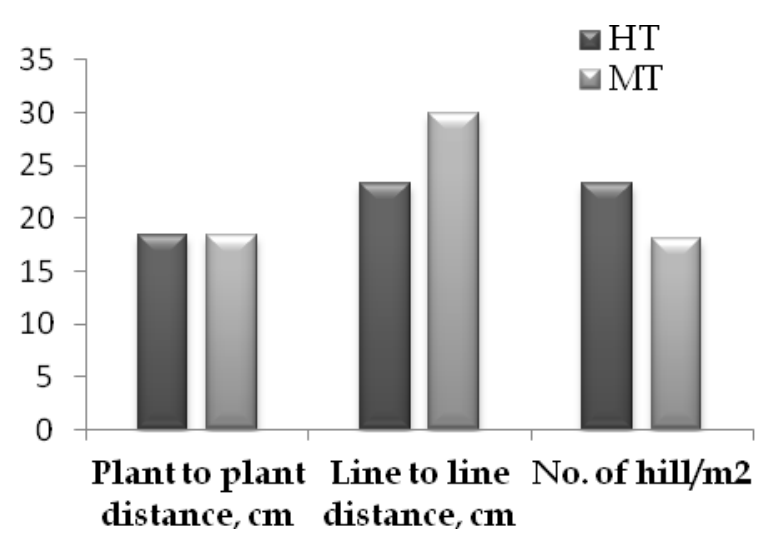

F

igure $2 \mathrm{~b}$. Hill density at Jhenaidah site

\section{Number of seedlings dispensed per hill}

Numbers of seedlings dispensed per hill in mechanically transplanted fields are given in Figure 3. Number of seedling dispensed per hill depends on the seedling density in tray and seedling density setting. Number of seedlings dispensed per hill varied in different plots. In most of the cases, 2-3 numbers of seedlings dispensed per hill. Single vigor seedling is enough to satisfy agronomic requirement. To avoid missing hill, number of seedling dispensed should be more than one.

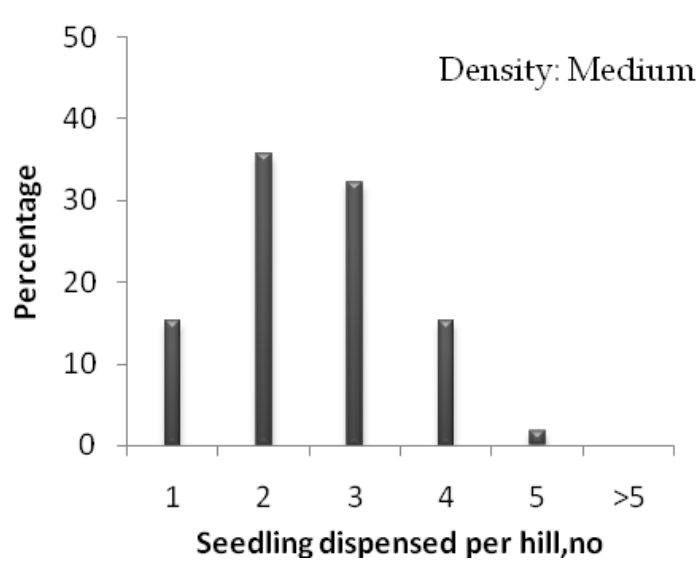

(a)Rangpur

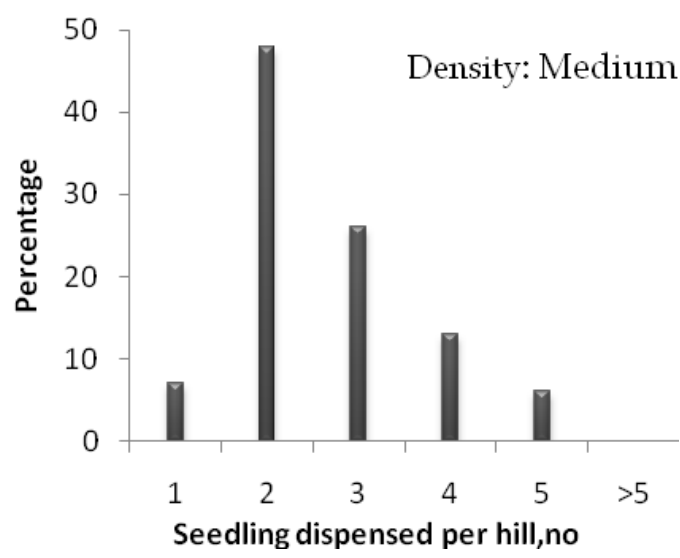

(b) Jhenaidah

Figure 3. Seedling density in mechanical transplanted field

\section{Plant population per hill}

Yield is closely related to plant population. Figure 4 shows that, plant populations increased with time in both practices. Plant population was higher in mechanically transplanted plots than hand transplanted plots.

\section{Plant height}

Plant height observed similar in both practices (Figure 5). Plant height increased progressively overtime. Plant height followed rapid growth from 20 to 60 DAT in both practices. 


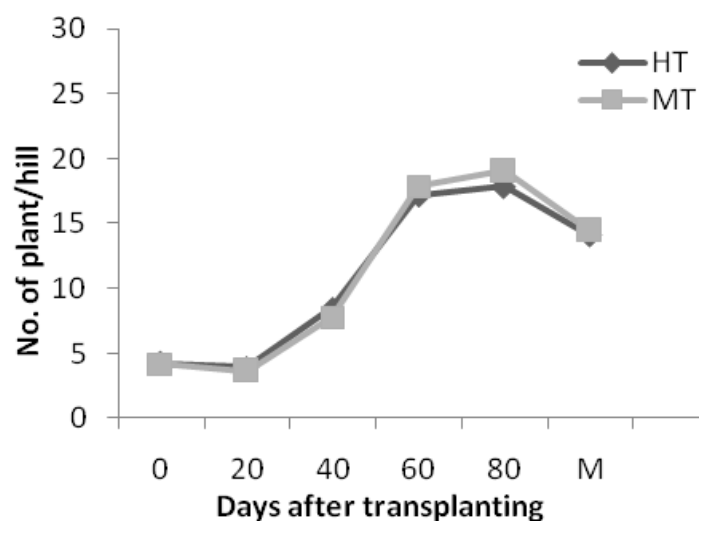

a.Rangpur

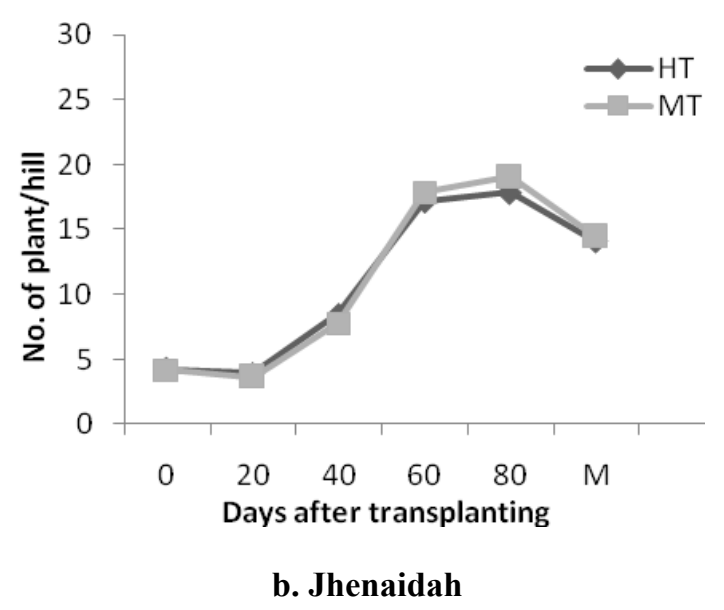

Figure 4. Hill density of mechanical and hand Transplanting

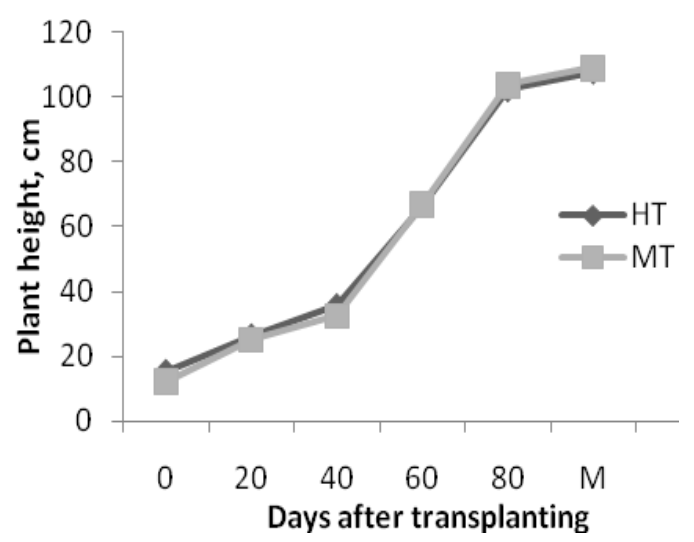

a.Rangpur

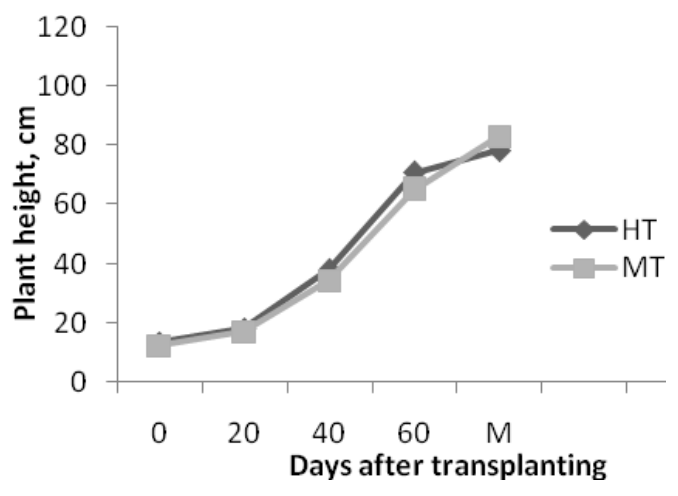

b. Jhenaidah

Figure 5. Plant height mechanical and hand transplanting

\section{Tillering pattern}

The effect of management practices on tillering pattern boro season rice in both locations is shown in Figure 6. In both practices, the tiller production sharply increased from 20 DAT and the maximum tillering stage reached in 60 DAT.

\section{Stage-wise plant population}

Figure 7 showed the stage-wise tiller production under different practices. MT produced higher tillers at all the studied stages and it was more pronounced at maximum tiller stage.

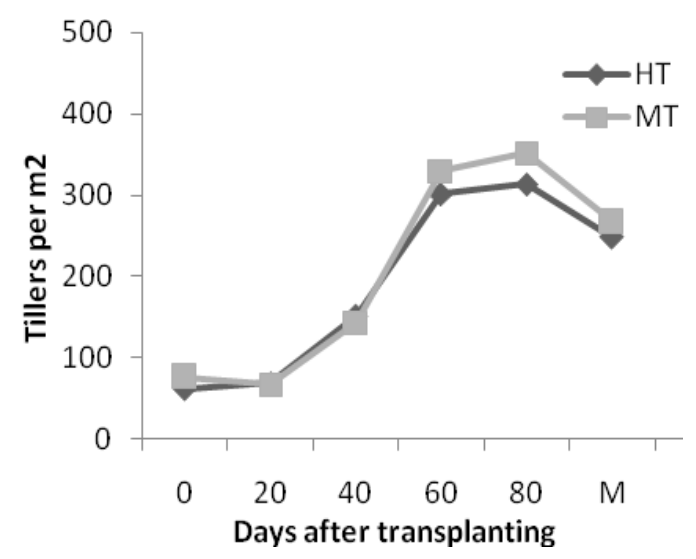

a. Rangpur 


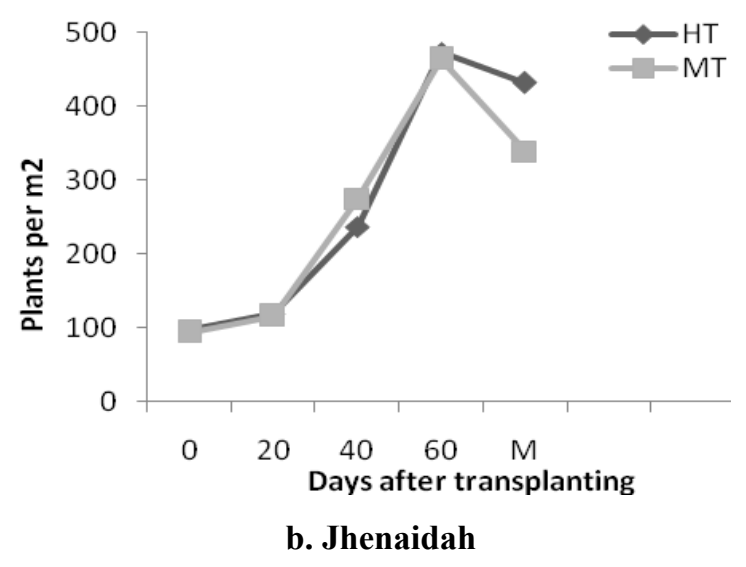

Figure 6. Tillering pattern of mechanical and hand transplanting

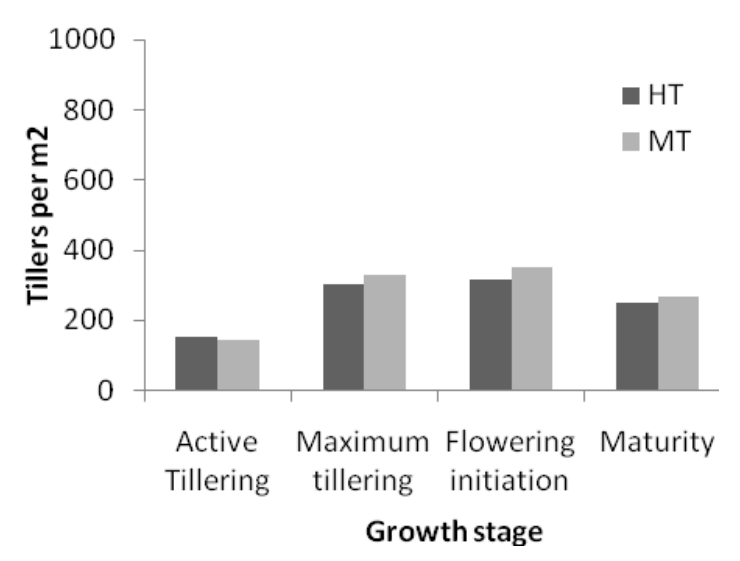

a. Rangpur

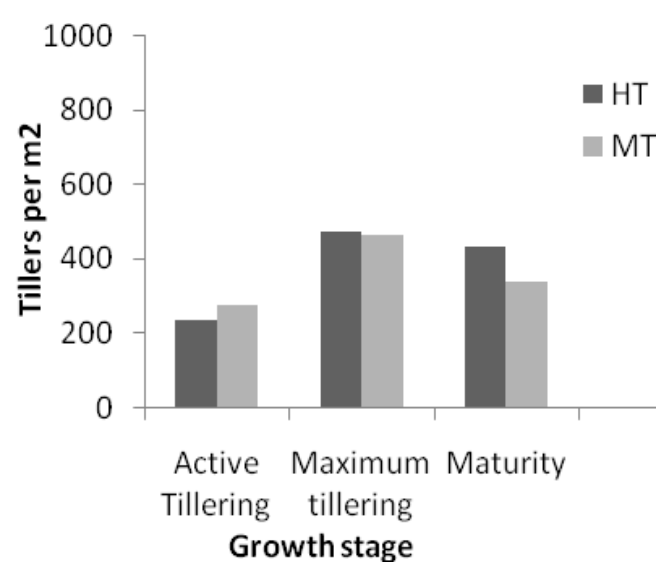

b. Jhenaidah

Figure 7. Stage-wise plant population in mechanical and hand transplanting

\section{Yield and yield contributing character}

Data were statistically analyzed on treatments over location. Table 2 shows the yield and yield contributing character under two transplanting methods. MT produced significantly higher grain yield $(9-14 \%)$ than HT in both locations due to use of tender age seedling. Grain yield of both practices showed less in Jhenaidah due to damage crop by hail storm. Hail storm occurred after maximum tillering stage (after 60 days of transplanting, 06-04-2015) and some crops revived within the panicle initiation stage.

Table 2. Yield and yield contribution character

\begin{tabular}{llcccccc}
\hline Location & Treatment & $\begin{array}{c}\text { Grain } \\
\text { yield, t/ha }\end{array}$ & $\begin{array}{c}\text { Panicle, } \\
\mathbf{n o .} / \mathbf{m}^{\mathbf{2}}\end{array}$ & $\begin{array}{c}\text { Panicle } \\
\text { length, } \mathbf{c m}\end{array}$ & $\begin{array}{c}\text { Grain, } \\
\mathbf{n o .} / \mathbf{m}^{\mathbf{2}}\end{array}$ & $\begin{array}{c}\text { Sterility, } \\
\mathbf{\%}\end{array}$ & $\begin{array}{c}\mathbf{1 0 0 0} \text {-grain } \\
\text { mass }\end{array}$ \\
\hline Rangpur & HT & 5.05 & 211.50 & 21.21 & 18647 & 31.97 & 22.40 \\
& MT & 5.57 & 237.33 & 22.90 & 21306 & 29.68 & 22.32 \\
Jhenaidah & HT & 3.93 & 332.33 & 19.19 & 23418 & 26.47 & 22.43 \\
& MT & 4.50 & 265.50 & 20.79 & 25461 & 17.83 & 23.06 \\
CV, \% & & 7.98 & 18.21 & 6.55 & 16.91 & 13.75 & 8.01 \\
LSD $_{0.05}$ & L & 0.33 & 41.46 & 1.20 & 3261 & 3.17 & NS \\
& T & 0.33 & NS & 1.20 & NS & 3.17 & NS \\
& L x T & NS & 58.64 & NS & NS & 4.48 & NS \\
\hline
\end{tabular}


Transplanting methods showed significant effect on panicle length. MT produced longer panicle than HT in both site. Sterility percentage showed significantly higher in HT than MT. Combined effect of location and treatment showed insignificant on panicle number, grain per unit area and 1000 grain weight.

\section{Labor requirement in crop production}

Effect of transplanting method on labor requirement is very important. Table 3 showed the labor requirement from seedbed preparation to winnowing in rice production.

Table 3. Labor requirement in hand and mechanical transplanting in two locations

\begin{tabular}{|c|c|c|c|c|}
\hline \multirow[b]{2}{*}{ Activity } & \multicolumn{2}{|c|}{ Rangpur, man-hr/ha } & \multicolumn{2}{|c|}{ Jhenaidah, man-hr/ha } \\
\hline & Hand & Mechanical & Hand & Mechanical \\
\hline Seedbed preparation & 1.96 & - & 1.82 & - \\
\hline Seeding & 0.35 & - & 3.59 & - \\
\hline Irrigation & 24 & - & 24.01 & - \\
\hline Seedling uprooting & 29.01 & - & 8.13 & - \\
\hline Seedling raising & - & - & - & - \\
\hline Sieving, & - & 6.93 & - & 10.73 \\
\hline Tray preparation & - & 41.58 & - & 42.93 \\
\hline Seeding & - & 4.79 & - & 10.31 \\
\hline Irrigation & - & 18.07 & - & 13.3 \\
\hline Subtotal & $\begin{array}{c}55.32 \\
(8.61 \%)\end{array}$ & $\begin{array}{c}71.37 \\
(13.15 \%)\end{array}$ & $\begin{array}{c}37.55 \\
(5.31 \%)\end{array}$ & $\begin{array}{c}77.27 \\
(12.76 \%)\end{array}$ \\
\hline \multicolumn{5}{|l|}{ Land preparation } \\
\hline Tillage & $\begin{array}{c}8.53 \\
(1.33 \%)\end{array}$ & $\begin{array}{c}10.23 \\
(1.88 \%)\end{array}$ & $\begin{array}{c}9.04 \\
(1.28 \%)\end{array}$ & $\begin{array}{c}9 \\
(1.49 \%)\end{array}$ \\
\hline Leveling & $\begin{array}{c}4.35 \\
(0.68 \%)\end{array}$ & $\begin{array}{c}4.74 \\
(0.87 \%)\end{array}$ & $\begin{array}{c}2 \\
(0.28 \%)\end{array}$ & $\begin{array}{c}2.02 \\
(0.33 \%)\end{array}$ \\
\hline Transplanting & $\begin{array}{c}123.59 \\
(19.24 \%)\end{array}$ & $\begin{array}{c}9.86 \\
(1.82 \%)\end{array}$ & $\begin{array}{c}149.92 \\
(21.19 \%)\end{array}$ & $\begin{array}{c}10.02 \\
(1.65 \%)\end{array}$ \\
\hline Weeding & $\begin{array}{c}99.99 \\
(15.57 \%)\end{array}$ & $\begin{array}{c}100.01 \\
(18.43 \%)\end{array}$ & $\begin{array}{c}170.01 \\
(24.02 \%)\end{array}$ & $\begin{array}{c}170.04 \\
(28.08 \%)\end{array}$ \\
\hline Insecticide spray & $\begin{array}{c}9.96 \\
(1.55 \%)\end{array}$ & $\begin{array}{c}5.89 \\
(1.09 \%)\end{array}$ & $\begin{array}{c}5.01 \\
(0.71 \%)\end{array}$ & $\begin{array}{c}5.04 \\
(0.83 \%)\end{array}$ \\
\hline Fertilizer application & $\begin{array}{c}3.68 \\
(0.57 \%)\end{array}$ & $\begin{array}{c}3.67 \\
(0.68 \%)\end{array}$ & $\begin{array}{c}3.97 \\
(0.56 \%)\end{array}$ & $\begin{array}{c}4 \\
(0.66 \%)\end{array}$ \\
\hline Harvesting & $\begin{array}{c}129.97 \\
(20.23 \%)\end{array}$ & $\begin{array}{c}130.01 \\
(23.95 \%)\end{array}$ & $\begin{array}{c}149.95 \\
(21.19 \%)\end{array}$ & $\begin{array}{c}150.03 \\
(24.78 \%)\end{array}$ \\
\hline Carrying & $\begin{array}{c}45.01 \\
(7.01 \%)\end{array}$ & $\begin{array}{c}44.99 \\
(8.29 \%)\end{array}$ & $\begin{array}{c}41.99 \\
(5.93 \%)\end{array}$ & $\begin{array}{l}42.02 \\
6.94 \%\end{array}$ \\
\hline Threshing & $\begin{array}{c}109.99 \\
(17.12 \%)\end{array}$ & $\begin{array}{c}110.01 \\
(20.27 \%)\end{array}$ & $\begin{array}{c}80.35 \\
(11.35 \%)\end{array}$ & $\begin{array}{c}80.07 \\
(13.22)\end{array}$ \\
\hline Winnowing & $\begin{array}{c}51.99 \\
(8.09 \%)\end{array}$ & $\begin{array}{c}51.96 \\
(9.57 \%)\end{array}$ & $\begin{array}{c}57.87 \\
(8.18 \%)\end{array}$ & $\begin{array}{c}56.04 \\
(9.25 \%)\end{array}$ \\
\hline Total & 642.38 & 542.74 & 707.66 & 605.55 \\
\hline
\end{tabular}


Total labor requirement for production of one hectare rice transplanting was 642-708 man-hr for transplanting by hand and 542-606 man-hr for mechanical transplanting. Labor requirement in hand transplanting ranged from 123-150 man-hr per hectare. It indicated that hand transplanting appeared as labor intensive works in rice production. Labor requirement in hand transplanting showed higher in Jhenaidah site due to maintain exact line to line and plant to plant spacing. It is not the common scenario whole over the country. In mechanical transplanting, labor requirement ranged from 9.5-10.5 man-hr per hectare in both sites. The labor requirement from seedling establishment to transplanting showed 179-187 man-hr/ha in HT and 81-87 man-hr/ha in MT i.e. 53-55\% labor can be saved in mechanical transplanting if all other applications remain same. Traditional seed preparation required 5$9 \%$ labor whereas $12-13 \%$ required in seedling raised in tray suitable for mechanical transplanting. Among the crop production stages, manual harvesting using sickle required highest (20-25\%) labor. Hand transplanting required the second highest labor requirement (19-22\%) in crop production whereas $1.65-2 \%$ labor required in mechanical transplanting. Mechanical intervention in crop production drastically reduced the labor requirement which can offset the peak labor demand.

\section{Economic analysis}

Table 4 showed the item wise costs of crop establishment and total production costs. Price of the inputs and outputs collected from the local market. Land preparation, irrigation, weeding, fertilizer, harvesting, carrying, threshing and winnowing costs were nearly same for both the transplanting method on both sites. Seed costs and transplanting cost varied depending on the transplanting method. Seedling raising cost showed $10 \%$ higher in tray type than traditional method.

Table 4a. Cost of production under different transplanting methods in Rangpur

\begin{tabular}{lcc}
\hline \multicolumn{1}{c}{ Activity } & MT, Tk/ha & HT, Tk/ha \\
\hline Seedling raising & 4516 & 4061 \\
Land preparation & 7956 & 7956 \\
Transplanting & 986 & 6179 \\
Machine rental charge & 2594 & - \\
Fuel & 433 & - \\
Basal fertilizer & 11419 & 11419 \\
Urea application & 184 & 184 \\
Insecticide application & 3779 & 3779 \\
Weeding & 5000 & 5000 \\
Irrigation & 10500 & 10500 \\
Harvesting & 6498 & 6498 \\
Carrying & 2250 & 2250 \\
Threshing & 5500 & 5500 \\
Winnowing & 2600 & 2600 \\
Subtotal & $\mathbf{6 4 2 1 5}$ & $\mathbf{6 5 9 2 6}$ \\
Land value & 20000 & 20000 \\
Interest on investment & 2123 & 2149 \\
Subtotal & $\mathbf{2 2 1 2 3}$ & $\mathbf{2 2 1 4 9}$ \\
\hline Total production cost & $\mathbf{8 6 3 3 8}$ & $\mathbf{8 8 0 7 5}$ \\
\hline
\end{tabular}


Table $4 \mathrm{~b}$. Cost of production under different transplanting methods in Jhenaidah

\begin{tabular}{lcc}
\hline \multicolumn{1}{c}{ Activity } & MT, Tk/ha & HT, Tk/ha \\
\hline Seedling raising & 5602 & 3174 \\
Land preparation & 7767 & 7767 \\
Transplanting & 1059 & 7496 \\
Machine rental charge & 2786 & - \\
Fuel & 1051 & - \\
Basal fertilizer & 9600 & 9600 \\
Urea application & 200 & 200 \\
Insecticide application & 432 & 432 \\
Weeding & 8500 & 8500 \\
Irrigation & 1500 & 1500 \\
Harvesting & 7500 & 7500 \\
Carrying & 2100 & 2100 \\
Threshing & 3210 & 3210 \\
Winnowing & 1993 & 1993 \\
Subtotal & $\mathbf{5 3 3 0 0}$ & $\mathbf{5 3 4 7 2}$ \\
Land rental charge & 20000 & 20000 \\
Interest on investment & 1833 & 1837 \\
Subtotal & $\mathbf{2 1 8 3 3}$ & $\mathbf{2 1 8 3 7}$ \\
Total production cost & $\mathbf{7 5 1 3 3}$ & $\mathbf{7 5 3 0 9}$ \\
\hline
\end{tabular}

Cost of hand transplanting was higher than the cost of mechanical transplanting. Mechanical transplanter reduced the transplanting cost.

Effect of transplanting method on labor and material cost

The input cost in the form of labor and material from seedling establishment to winnowing for mechanical and hand transplanting are shown in the Table 5. In
Rangpur site, labor and material cost was almost similar in hand transplanting whereas in mechanical transplanting, labor cost is $12 \%$ lower than material cost. In Jhenaidah, labor cost of both system showed highest compared to material cost due higher labor requirement in weeding and higher labor price.

Table 5. Cost comparison of mechanical and hand transplanting in two locations

\begin{tabular}{lcccc}
\hline Parameter & \multicolumn{2}{c}{ Rangpur } & \multicolumn{2}{c}{ Jhenaidah } \\
& Hand & Mechanical & Hand & Mechanical \\
\hline Labor cost (Tk/ha) & 33070 & 28629 & 35157 & 31148 \\
& $(50.16)$ & $(44.58)$ & $(65.75)$ & $(58.44)$ \\
Material cost & 32855 & 35586 & 18315 & 22152 \\
(Tk/ha) & $(49.84)$ & $(55.42)$ & $(34.25)$ & $(41.56)$ \\
\hline Total cost & $\mathbf{6 5 9 7 3}$ & $\mathbf{6 3 8 8 7}$ & $\mathbf{5 3 8 1 9}$ & $\mathbf{5 2 9 5 0}$ \\
\hline
\end{tabular}

*Figure in the parentheses indicate the percentage 
Effect of transplanting methods on gross return, net return and benefit cost ratio

Table 6 shows effect of transplanting method on gross return and benefit cost-ratio (BCR). The gross return was calculated based on the market price of paddy and straw. The gross returns, net return and BCR obtained the highest in mechanical transplanting than hand transplanting method in both sites. The lowest BCR was obtained in the hand transplanting method and it was due to higher labor cost, higher seed rate and

higher planting cost for labor crisis. BCR of MT showed $13-15 \%$ higher than HT due to lower input cost and higher grain yield. From these results it could be concluded that Tk 11,357-11,441 per hectare will be saved for mechanical transplanting method over the hand transplanting method.

Table 6a. Effect on transplanting method on gross return, net return and benefit cost ratio (BCR) at Rangpur

\begin{tabular}{ccccccc}
\hline Treatment & $\begin{array}{c}\text { Input cost, } \\
\text { Tk/ha }\end{array}$ & $\begin{array}{c}\text { Return } \\
\text { from grain, } \\
\text { Tk/ha }\end{array}$ & $\begin{array}{c}\text { Return } \\
\text { from straw, } \\
\text { Tk/ha }\end{array}$ & $\begin{array}{c}\text { Gross } \\
\text { return, } \\
\text { Tk/ha }\end{array}$ & $\begin{array}{c}\text { Net return, } \\
\text { Tk/ha }\end{array}$ & $\begin{array}{c}\text { Benefit } \\
\text { Cost Ratio } \\
\text { (BCR) }\end{array}$ \\
\cline { 2 - 7 } & $\mathbf{A}$ & $\mathbf{B}$ & $\mathbf{C = A + B}$ & $\mathbf{D}$ & $\mathbf{E}$ & $\mathbf{F}$ \\
\hline MT & 86338 & 90513 & 12525 & 103038 & 16700 & 1.19 \\
HT & 88075 & 82063 & 11355 & 93418 & 5343 & 1.06 \\
\hline
\end{tabular}

Table 6b. Effect on transplanting method on gross return, net return and benefit cost ratio (BCR) at Jhenaidah

\begin{tabular}{ccccccc}
\hline Treatment & $\begin{array}{c}\text { Input cost, } \\
\text { Tk/ha }\end{array}$ & $\begin{array}{c}\text { Return from } \\
\text { grain, Tk/ha }\end{array}$ & $\begin{array}{c}\text { Return from } \\
\text { straw, Tk/ha }\end{array}$ & $\begin{array}{c}\text { Gross return, } \\
\text { Tk/ha }\end{array}$ & $\begin{array}{c}\text { Net return, } \\
\text { Tk/ha }\end{array}$ & $\begin{array}{c}\text { Benefit Cost } \\
\text { Ratio (BCR) }\end{array}$ \\
\cline { 2 - 7 } & $\mathbf{A}$ & $\mathbf{B}$ & $\mathbf{C = A + B}$ & $\mathbf{D}$ & $\mathbf{E}$ & $\mathbf{F}$ \\
\hline MT & 75133 & 78750 & 10125 & 88875 & 13742 & 1.18 \\
HT & 75309 & 68775 & 8835 & 77610 & 2301 & 1.03 \\
\hline
\end{tabular}

\section{Conclusion}

Mechanical transplanting increase grain yield, reduce the production costs and improve labor efficiency. It can be concluded that mechanical transplanting method is economic than the hand transplanting method.

\section{Acknowledgement}

The authors acknowledge funding provided by the Bill and Melinda Foundation through the CIMMYT implemented CSISA-II project especially Mr. Timothy Russel, CoP, CSISA-BD for the implementation of the project. The author indebted to Dr. Md. Shahidul Islam, PSO \& Head, Regional station, BRRI, Rangpur for providing technical support. The authors deeply express their gratitude to BRRI authority for providing research support and facilities. The authors highly praised to Dr. Kim Young Jung, Advisor at BRRI for editing the report.

\section{References}

Behera BK, Varshney BP, Goel AK (2009). Effect of puddling on puddled soil characteristics and performance of self-propelled transplanter in rice crop. The CIGR Ejournal, Vol. X. Manuscript PM 08020 .

Hunt D (1995). Farm Power and Machinery Management, Cost determination, $9^{\text {th }}$ edition, Iowa State University press, USA.

Mori Y (1975). Performance evaluation of rice transplanters evaluated by national test. JARQ. 9(3): 152-155. 
Rao MV, Pradhan SN (1973). Cultivation practices. Rice Production Manual, ICAR; 71-95.

Singh GTR, Sharma CW, Bockhop (1985). Field performance evaluation of a manual rice transplanter. J. Agril. Engg. Ress. 23: 259-268.
Tripathi SK, Jena HK, Panda PK (2004). Selfpropelled rice transplanter for economizing labor, Indian fmg., 54: 23-25. 